\title{
Ultraviolet-ozone treatment reduces levels of disease-associated prion protein and prion infectivity Christopher J Johnson ${ }^{1,4}$, PUPA Gilbert ${ }^{2}$, Debbie McKenzie ${ }^{1,5}$, Joel A Pedersen ${ }^{3}$ and Judd M Aiken*1,6
}

\begin{abstract}
Address: ${ }^{1}$ Department of Comparative Biosciences, University of Wisconsin - Madison, 1656 Linden Dr, Madison, WI 53706, USA, ${ }^{2}$ Department of Physics, University of Wisconsin - Madison, 1150 University Ave, Madison, WI 53706, USA, ${ }^{3}$ Department of Soil Science \& Molecular and Environmental Toxicology Center, University of Wisconsin - Madison, 1525 Observatory Dr, Madison, WI 53706, USA, ${ }^{4}$ Current address: US Geological Survey, Biological Resources Division, National Wildlife Health Center, 6006 Schroeder Rd., Madison, WI. 53711, USA, ${ }^{5}$ Current address: Alberta Centre for Prions and Protein Folding Diseases, Department of Biological Sciences, University of Alberta, Edmonton, Alberta, T6G 2M8, Canada and ${ }^{6}$ Current address: Alberta Centre for Prions and Protein Folding Diseases, Department of Agricultural, Food and Nutritional Sciences, University of Alberta, Edmonton, Alberta, T6G 2M8, Canada

Email: Christopher J Johnson - cjjohnson@usgs.gov; PUPA Gilbert - pupa@physics.wisc.edu;

Debbie McKenzie - mckenzie@svm.vetmed.wisc.edu; Joel A Pedersen - joelpedersen@wisc.edu; Judd M Aiken* - aiken@svm.vetmed.wisc.edu

* Corresponding author
\end{abstract}

Published: 6 July 2009

BMC Research Notes 2009, 2:121 doi:10.1186/1756-0500-2-121
Received: 8 December 2008

Accepted: 6 July 2009

This article is available from: http://www.biomedcentral.com/l756-0500/2//2I

(C) 2009 Aiken et al; licensee BioMed Central Ltd.

This is an Open Access article distributed under the terms of the Creative Commons Attribution License (http://creativecommons.org/licenses/by/2.0), which permits unrestricted use, distribution, and reproduction in any medium, provided the original work is properly cited.

\begin{abstract}
Background: Transmissible spongiform encephalopathies (TSEs) are a group of fatal neurodegenerative diseases caused by novel infectious agents referred to as prions. Prions appear to be composed primarily, if not exclusively, of a misfolded isoform of the cellular prion protein. TSE infectivity is remarkably stable and can resist many aggressive decontamination procedures, increasing human, livestock and wildlife exposure to TSEs.

Findings: We tested the hypothesis that UV-ozone treatment reduces levels of the pathogenic prion protein and inactivates the infectious agent. We found that UV-ozone treatment decreased the carbon and prion protein content in infected brain homogenate to levels undetectable by dryashing carbon analysis or immunoblotting, respectively. After 8 weeks of ashing, UV-ozone treatment reduced the infectious titer of treated material by a factor of at least $10^{5}$. A small amount of infectivity, however, persisted despite UV-ozone treatment. When bound to either montmorillonite clay or quartz surfaces, PrPTSE was still susceptible to degradation by UV-ozone.

Conclusion: Our findings strongly suggest that UV-ozone treatment can degrade pathogenic prion protein and inactivate prions, even when the agent is associated with surfaces. Using larger UVozone doses or combining UV-ozone treatment with other decontaminant methods may allow the sterilization of TSE-contaminated materials.
\end{abstract}

\section{Findings}

Transmissible spongiform encephalopathies (TSEs, prion diseases) are a group of fatal neurodegenerative diseases that affect humans and a variety of domestic and wild mammals [1]. The disease agents responsible for TSEs are referred to as prions and are comprised primarily, if not solely, of a misfolded isoform of the prion protein, designated PrPTSE, derived from the normal cellular isoform of 
the protein $\left(\mathrm{PrPC}^{\mathrm{C}}\right)$ [2]. Whereas $\mathrm{PrPC}$ is susceptible to hydrolysis and degradation, the conformation adopted by PrPTSE affords it protection from numerous aggressive treatments that inactivate conventional pathogens [3]. Incomplete sterilization of medical devices has resulted in iatrogenic transmission of human TSEs [4]. Development of effective prion decontamination methods represents an important goal in safeguarding human and animal health.

Ozone is a strong oxidant $\left(E_{H}^{0}=2.07 \mathrm{~V}\right)$ that chemically alters and inactivates numerous chemical contaminants and pathogens [5]. Ozone can be generated by corona discharge, cold plasma and ultraviolet (UV)-ozone devices [6]. In the case of UV-ozone generators, ultraviolet light at two wavelengths contributes to ozone generation and contaminant removal from surfaces: $185 \mathrm{~nm}$ photons dissociate $\mathrm{O}_{2}$ to $\mathrm{O}$ forming ozone $\left(\mathrm{O}_{3}\right)$ via a radical reaction, and light at $254 \mathrm{~nm}$ excites bonds present in some organic contaminants [7]. UV-ozone treatment can be conducted at room temperature and pressure, is low-cost and has been successfully employed to remove carbon from $\mathrm{Si}$ microchip surfaces, $\mathrm{x}$-ray optics and samples being prepared for elemental analyses (e.g., spectromicroscopy) [810]. Degradation of organic compounds by UV-ozone involves breakage of carbon-carbon bonds and $\mathrm{CO}_{2}$ evolution [7], and inactivation of proteins by ozone appears to occur, at least initially, via side-chain oxidation and structural rearrangement [11]. Although UV-based systems produce much less ozone and require substantially longer exposure times than other generators, spectromicroscopic analyses have demonstrated that UV-ozone effectively removes carbon from samples while preserving the ultrastructure of treated samples $[9,10]$. In the present study, we investigated the degree to which UV-ozone inactivated prions deposited on Si wafers or associated with quartz or montmorillonite clay (Mte) surfaces, using conditions identical to those that remove carbon from spectromicroscopy samples.

The Hyper strain of hamster-passaged transmissible mink encephalopathy agent (HY) was used in all experiments [12]. Brain homogenate $(\mathrm{BH}), 10 \% \mathrm{w} / \mathrm{v}$ in $\mathrm{ddH}_{2} \mathrm{O}$, was either deposited on inert $\mathrm{Si}$ wafer substrates $(8 \mathrm{~cm} \times 1 \mathrm{~cm}$ $\times 500 \mu \mathrm{m}$ ) or, for studies examining degradation of PrPTSE bound to particle surfaces, was allowed to adsorb to particles using published protocols [13]. Briefly, following clarification by centrifugation, $30 \mu \mathrm{L} \mathrm{HY} \mathrm{BH}$ was incubated for $2 \mathrm{~h}$ in $10 \mathrm{mM} \mathrm{NaCl}$ with 0.5 or $3.2 \mathrm{mg}$ of Mte or quartz microparticles, respectively, or in the absence of particles for control samples. All solutions were air-dried overnight and UV-ozone treatment was initiated the following day. Samples were prepared such that UV-ozone exposure was terminated on the same day for all samples. Aliquots of all particle-free samples (0-8 weeks treatment) were prepared for total carbon analysis (dry ashing method, Leco CNS-2000 analyzer) [14], immunoblotting using monoclonal antibody 3F4 and published protocols [13], and intracerebral inoculation into Syrian hamsters (Mesocricetus auratus, cared for in accordance with institutional animal care protocols). Samples containing particles were prepared for immunoblotting. Digestion of HY BH with $50 \mu \mathrm{g} \cdot \mathrm{mL}^{-1}$ proteinase $\mathrm{K}(\mathrm{PK})$ for 30 minutes indicated the initial presence of $\operatorname{PrPT}^{\mathrm{TSE}}$ in the starting material.

UV-ozone exposure was conducted in an ashing oven consisting of enclosed metal housing equipped with a custom-made, cold-cathode, low-pressure, grid mercury lamp (producing UV radiation with wavelengths of 185

\section{a}
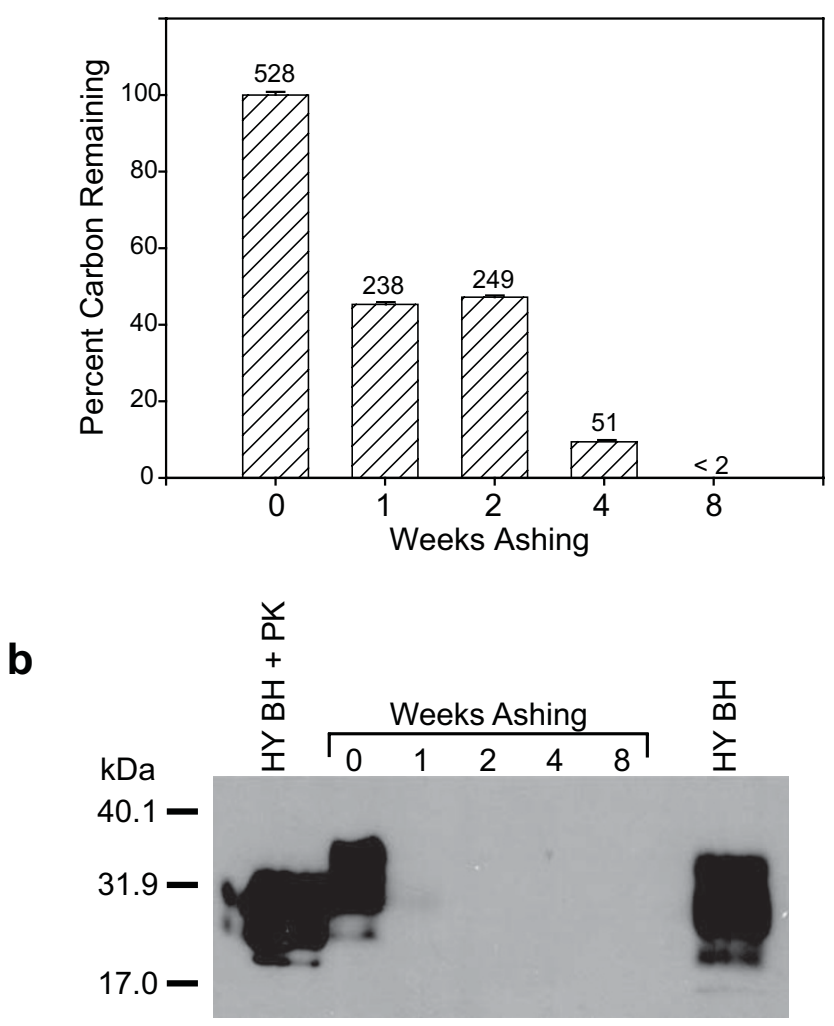

\section{Figure I}

UV-ozone treatment decreases carbon and PrPTSE levels. (a) Total (organic and inorganic) carbon was measured following 0, I, 2, 4 or 8 weeks of UV-ozone treatment. Bars represent means \pm one standard deviation; numerical values above bars indicate the mean mass of carbon remaining in $\mu$ g. Experiment is representative of two independent replicates. (b) Immunoblot analysis of prion protein following ozone ashing for the indicated time period. Hyper-infected brain homogenate $(\mathrm{HY} \mathrm{BH})$ and $\mathrm{HY} \mathrm{BH}$ treated with 50 $\mu \mathrm{g} \cdot \mathrm{mL}^{-1}$ proteinase $\mathrm{K}$ (PK) demonstrate the presence of PrPTSE before ashing. Immunoblot used anti-prion protein antibody $3 \mathrm{~F} 4$. 
and $254 \mathrm{~nm} ; 1.5 \mathrm{~mW} \cdot \mathrm{cm}^{2}$ at $1 \mathrm{in}$ ) mounted on a $5 \mathrm{~cm} \times$ $15 \mathrm{~cm}$ Alzak reflector (Jelight Co., Irvine, CA). Dry air $\left(<1 \%\right.$ relative humidity, $20^{\circ} \mathrm{C}$ ) was pumped into the oven $\left(1.2 \mathrm{~L} \cdot \mathrm{min}^{-1}\right)$ to purge $\mathrm{CO}_{2}$ and replenish $\mathrm{O}_{2}$ for ozone generation. Silicon substrates with dried brain homogenate were placed $2 \mathrm{~mm}$ from the lamp and ashed for 0-8 weeks. After ashing, residual brain material was removed from substrates by agitation in phosphate buffered saline (PBS, for carbon analysis, immunoblotting and bioassay) or $10 \times$ SDS-PAGE sample buffer $(100 \mathrm{mM}$ Tris $\mathrm{pH} 8.0$, $10 \%$ SDS, $7.5 \mathrm{mM}$ EDTA, $100 \mathrm{mM}$ dithiothreitol, 30\% glycerol, for immunoblotting only) at $95^{\circ} \mathrm{C}$. Material was removed from the silicon surface until the substrate appeared visibly clean and mirror-like. Sample buffer extraction of residual PrPTSE is a harsh treatment that denatures the protein and ranks among the most effective known means of removing PrPTSE from surfaces $[13,15]$. Test extractions with $10 \times$ SDS-PAGE sample buffer at $95^{\circ} \mathrm{C}$ or PBS at $20^{\circ} \mathrm{C}$ were equally effective on removing both ashed and unashed material from Si wafers (data not shown). For the non-ashed control sample (0 weeks), brain material was removed from the Si substrate following overnight drying.

UV-ozone ashing of brain homogenate (BH) from TSEinfected hamsters resulted in a time-dependent loss of car- bon (Figure 1a). Approximately 50\% of the carbon was lost after 1 week of ashing (initial value of $528 \pm 2 \mu \mathrm{g}$ was reduced to $238 \pm 1 \mu \mathrm{g})$. Interestingly, no decrease in carbon content occurred during the second week of UVozone treatment $(249 \pm 1 \mu \mathrm{g})$. At 4 weeks, the carbon content had decreased to $\sim 10 \%$ of the initial concentration $(51 \pm 2 \mu \mathrm{g})$. Carbon was not detected after 8 weeks of ashing, indicating that $<2 \mu \mathrm{g} \mathrm{C}$ remained.

Non-linear carbon loss in HY BH samples could indicate resistance of a subset of biomolecules to UV-ozone degradation. Previous work has shown that DNA and RNA are substantially more susceptible to ozone attack than proteins [16] and dried proteins are particularly resistant to ozone action [11]. Experiments investigating sample thickness, biomolecule composition and carbon loss kinetics may provide insight into the cause of the observed non-linearity in carbon loss from $\mathrm{BH}$.

UV-ozone treatment reduced PrPTSE levels in a timedependent manner (Figure 1b). After one week of ashing, prion protein immunoreactivity was reduced to nearly undetectable levels by immunoblotting and after two weeks, levels were below the limits of immunoblotting detection. Our previous work has shown that similar reductions in immunoreactivity correspond to at least a

Table I: UV-ozonation decreases infectious TSE titer and increases disease incubation.

\begin{tabular}{|c|c|c|c|c|}
\hline Inoculum & Positive/Total Animals & $\begin{array}{l}\text { Onset of Clinical } \\
\text { Symptoms (dpi) }\end{array}$ & $\begin{array}{c}\text { Estimated Titer }\left(\text { ID }_{50}\right. \\
\text { per } 50 \mu \mathrm{L} \text { dosage })\end{array}$ & $\begin{array}{c}\text { Approximate } \\
\text { Reduction in Titer }\end{array}$ \\
\hline \multicolumn{5}{|l|}{$\begin{array}{l}\text { Dilutions of Starting } \\
\text { Material }\end{array}$} \\
\hline HY BH $(10 \% w / v)$ & $4 / 4$ & $67 \pm 0 *$ & $10^{6}-10^{7}$ & Not applicable \\
\hline $\mathrm{HY} \mathrm{BH}$ ( $10^{2}$ dilution factor) & $8 / 8$ & $86 \pm 0 *$ & $10^{4}-10^{5}$ & $10^{2}$ \\
\hline $\mathrm{HY} \mathrm{BH}$ ( $10^{4}$ dilution factor) & $8 / 8$ & $107 \pm 0 *$ & $10^{2}-10^{3}$ & $10^{4}$ \\
\hline $\mathrm{HY} \mathrm{BH}$ ( $10^{6}$ dilution factor) & $2 / 8$ & $141,156 t, \ddagger$ & $0-10^{1}$ & $10^{6}$ \\
\hline PBS & $0 / 4$ & $>365 \ddagger$ & 0 & Not applicable \\
\hline
\end{tabular}

\section{UV-ozone Treated \\ Material}

\begin{tabular}{lcccc}
\hline $\begin{array}{l}\mathrm{HY} \mathrm{BH}(10 \% \mathrm{w} / \mathrm{v}) \text { ashed } 4 \\
\text { weeks }\end{array}$ & $4 / 4$ & $120 \pm 10^{*}$ & $10^{1}-10^{2}$ & $10^{5}$ \\
\hline $\begin{array}{l}\mathrm{HY} \mathrm{BH}(10 \% \mathrm{w} / \mathrm{v}) \text { ashed } 8 \\
\text { weeks }\end{array}$ & $5 / 7$ & $127,136,136,136,141+, \neq$ & $1-10^{1}$ & $10^{6}$ \\
\hline
\end{tabular}

* Mean days post inoculation (dpi) \pm SD to onset of clinical symptoms of TSE infection

† Number of dpi to onset of clinical TSE symptoms for each clinically-affected animal in the group

$\ddagger$ Animals showing no clinical signs of TSE infection were sacrificed 365 days post-inoculation 


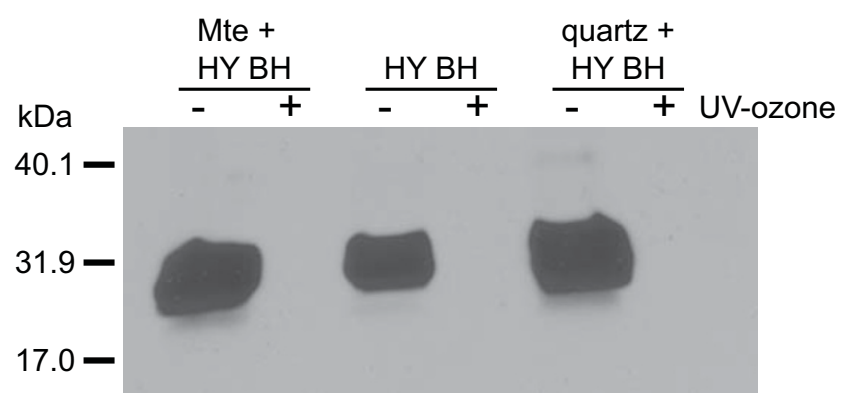

Figure 2

Susceptibility of Mte or quartz bound PrPTSE to UVozone degradation. Immunoblot analysis of PrP immunoreactivity following 7 days of UV-ozonation $(+)$ or incubation without UV-ozone (-) of Hyper-infected brain homogenate (HY BH) or HY BH bound to montmorillonite clay (Mte) or quartz. Immunoblot used anti-prion protein antibody 3F4.

200-fold loss of PrPTSE [17]. As expected, prion protein levels remained below the limit of detection in samples exposed to either 4 or 8 weeks of UV-ozone.

Intracerebral inoculation of samples into hamsters allowed direct assessment of the degree to which UVozone treatment diminished the infectious titer of ashed sample extracts. Table 1 presents the results obtained from 43 hamsters inoculated with UV-ozone treated (11 animals) and untreated infectious $\mathrm{BH}$ at various dilutions (32 animals), and the time to onset of clinical symptoms after inoculation. Weanling hamsters were intracerebrally dosed with ozone-treated material or a dilution series of the starting $\mathrm{BH}$ as a control on which to base estimates of remaining infectious titer in ashed samples. Each $50 \mu \mathrm{L}$ sample of undiluted, unashed $\mathrm{BH}$ contained $10^{6}-10^{7}$ infectious units [12]. Based on the dilution series, $\sim 10^{2}$ infectious units of TSE agent remained in BH after 4 weeks ashing (Table 1). With material which had been subjected to 8 weeks of ashing, two of seven inoculated hamsters did not succumb to disease within a 365 -day period (Table 1). UV-ozone clearly reduced the titer of ashed TSE agent. Precise determination of low prion titers is challenging [18], but the bioassay data indicate that the UVozone ashing conditions used here reduced TSE agent titer by at least a factor of $10^{5}$ and possibly more.

To test whether UV-ozone is capable of degrading prions bound to surfaces, we bound HY BH to two particles with different surfaces properties, namely Mte and quartz [13], and subjected both particle- and nonparticle-associated HY BH to 1 week of UV-ozone treatment (Figure 2). Samples prepared and incubated identically, but not exposed to UV-ozone, served as controls. Following ozonation or incubation, all samples were extracted with $10 \times$ sample buffer, a harsh treatment capable of removing approximately 95\% of PrPTSE from mineral surfaces $[13,15]$. No prion protein immunoreactivity was detectable in any of the UV-ozone treated samples suggesting UV-ozone is capable of degrading PrPTSE bound to surfaces.

Our results indicate that, in a controlled setting, that UVozone treatment degrades PrPTSE and inactivates prions. The relative contributions of ozone and ultraviolet light toward reducing PrPTSE levels are difficult to ascertain in our system as UV light is required for ozone production. We hypothesize that much of the observed degradation and inactivation resulted from ozone exposure for the following reasons. First, a reduction in carbon content, such as that observed in Figure 1a, is a characteristic effect of ozone and not of UV radiation [7]. Second, in aqueous media, proteins in general and TSE infectivity in particular, resist large doses of UV radiation [19], and dried biomolecules, such as those in our system, exhibit more resistance to UV inactivation than do wet samples $[20,21]$.

We consider it unlikely that UV-ozone treatment caused irreversible binding of PrPTSE to all tested surfaces (viz. Si, Mte and quartz), due to (1) substantial differences in surfaces properties among the materials, (2) previous reports indicating that proteins are more easily removed from surfaces following ozonation $[22,23]$ and (3) the efficacy of $10 \times$ sample buffer in removing avidly-bound PrPTSE from mineral surfaces $[13,15]$. Bioassay of the ozone-treated Mte or quartz bound PrPTSE will clarify the extent to which UV-ozone affects surface-bound prions.

In the present study, we employed a gentle UV-ozonation approach. Use of more aggressive UV-ozone treatment (e.g., by use of a higher wattage lamp), other techniques that produce higher ozone concentrations, ozone in combination with either other species of reactive oxygen or with other decontaminants might more effectively diminish prion titers. The hamster TSE strains, HY and $263 \mathrm{~K}$, are structurally related [24]; $\mathrm{HY}$ is as resistant to guanidine denaturation and PK digestion as $263 \mathrm{~K}$ and Sc237 strains $[25,26]$. The stability of the HY strain and its degradation by UV-ozone suggest that this method may have utility in decontaminating other prion strains, and investigation into UV-ozonation to decontaminate human strains or prions bound to stainless steel surfaces, as a model for surgical instruments, is warranted.

\section{Abbreviations}

BH: brain homogenate; dpi: days post-inoculation; HY: Hyper strain of hamster-passaged transmissible mink encephalopathy agent; Mte: montmorillonite clay; PAGE: polyacrylamide gel electrophoresis; PBS: phosphate buffered saline; PK: proteinase K; PrPC: cellular prion protein; PrP: prion protein; PrPTSE: disease-associated prion protein; TSE: transmissible spongiform encephalopathy; UV: ultraviolet. 


\section{Competing interests}

The authors declare that they have no competing interests.

\section{Authors' contributions}

CJJ and PUPAG conceived the study, designed and performed the experiments, analyzed the data and wrote the manuscript. DM, JAP and JMA analyzed the data and wrote the manuscript. All authors read and approved the final manuscript.

\section{Acknowledgements}

The authors thank Drs. Chad Johnson for assistance with the animal bioassay, Bradley H. Frazer for helpful discussion, Richard Rubenstein for the gift of the 3F4 antibody, Roger Hansen for constructing the UV-ozone ashing chamber and two anonymous reviewers for their constructive comments. Carbon measurements were made at the University of Wisconsin Soil and Plant Analysis Laboratory. Work was supported by DOD grants DAMD I7-03-1-0369 and DAMDI7-03-I-0294 and NSF grants CHE\&DMR-06I3972 and PHY-06460I8. Ozone ashing was performed at the Synchrotron Radiation Center, supported by NSF award DMR-

0537588. PUPA Gilbert was previously publishing as Gelsomina De Stasio

\section{References}

I. Watts JC, Balachandran A, Westaway D: The expanding universe of prion diseases. PLoS Pathog 2006, 2:e26.

2. Prusiner SB: Prions. Proc Natl Acad Sci USA 1998, 95: I3363-I 3383.

3. Taylor DM: Inactivation of transmissible degenerative encephalopathy agents: A review. Vet J 2000, 159:10-17.

4. Brown P, Preece M, Brandel JP, Sato T, McShane L, Zerr I, Fletcher A, Will RG, Pocchiari M, Cashman NR, d'Aignaux JH, Cervenakova L, Fradkin J, Schonberger LB, Collins SJ: Iatrogenic CreutzfeldtJakob disease at the millennium. Neurology 2000, 55: I075-I08I.

5. Kim JG, Yousef AE, Dave S: Application of ozone for enhancing the microbiological safety and quality of foods: a review. J Food Prot 1999, 62:1071-1087.

6. Langlais $B$, Reckhow DA, Brink DR: Ozone in water treatment: Application and engineering: Cooperative research report. Lewis Publishers, Chelsea, Michigan, USA; 1991.

7. Vig JR: UV/Ozone Cleaning of Surfaces. J Vac Sci Technol A I985, 3:1027-1034.

8. Hansen RWC, Bissen M, Wallace D, Wolske J, Miller T: Ultraviolet Ozone Cleaning of Carbon-Contaminated Optics. Appl Opt 1993, 32:4I|4-4II6.

9. De Stasio G, Capozi M, Droubay TC, Mercanti D, Ciotti MT, Lorusso GF, Andres R, Suda T, Perfetti P, Tonner BP, Margaritondo G: The effect of ashing on cells: spectromicroscopy of physiological elements. Anal Biochem 1997, 252:106-109.

10. Gilbert B, Perfetti L, Hansen R, Mercanti D, Casalbore P, Andres R Perfetti P, Margaritondo G, De Stasio G: UV-ozone ashing of cells and tissues for spatially resolved trace element analysis. Front Biosci 2000, 5:A10-17.

II. Cataldo F: On the action of ozone on proteins. Polymer Degrad Stabil 2003, 82: I05-II4.

12. Bessen RA, Marsh RF: Identification of two biologically distinct strains of transmissible mink encephalopathy in hamsters. J Gen Virol 1992, 73:329-334.

13. Johnson CJ, Phillips KE, Schramm PT, McKenzie D, Aiken JM, Pedersen JA: Prions adhere to soil minerals and remain infectious. PLoS Pathog 2006, 2:e32.

14. Matejovic I: Determination of carbon and nitrogen in samples of various soils by the dry combustion. Commun Soil Sci Plant Anal 1997, 28: |499-I5|I.

15. Cooke CM, Rodger J, Smith A, Fernie K, Shaw G, Somerville RA: Fate of prions in soil: Detergent extraction of PrP from soils. Environ Sci Technol 2007, 41:8II-8I7.

16. Cataldo F: Ozone degradation of biological macromolecules: Proteins, hemoglobin, RNA, and DNA. Ozone Sci Eng 2006 28:317-328
17. Hinkley GT, Johnson C], Jacobson KH, Bartholomay C, McMahon KD McKenzie D, Aiken JM, Pedersen JA: Persistence of pathogenic prion protein during simulated wastewater treatment processes. Environ Sci Technol 2008, 42:5254-5259.

18. Masel J, Jansen VA: The measured level of prion infectivity varies in a predictable way according to the aggregation state of the infectious agent. Biochim Biophys Acta 200I, I 535:164-173.

19. Bellinger-Kawahara C, Cleaver JE, Diener TO, Prusiner SB: Purified scrapie prions resist inactivation by UV irradiation. J Virol 1987, 61:159-166.

20. Sarkar G, Sommer S: More light on PCR contamination. Nature 1990, 347:340-341.

2I. Tominaga M, Hirata N, Taniguchi I: UV-ozone dry-cleaning process for indium oxide electrodes for protein electrochemistry. Electrochem Commun 2005, 7:|423-|428.

22. Fukuzaki S: The use of gaseous ozone as a cleaning agent on stainless steel surfaces fouled with bovine protein. Ozone $\mathrm{Scl}$ Eng 2006, 28:303-308.

23. Urano H, Fukuzaki S: Facilitation of cleaning of alumina surfaces fouled with heat-treated bovine serum albumin by ozone treatment. J Food Prot 200I, 61:108-1 I2.

24. Caughey B, Raymond GJ, Bessen RA: Strain-dependent differences in beta-sheet confromations of abnormal prion protein. J Biol Chem 1998, 273:32230-32235.

25. Peretz D, Scott MR, Groth D, Williamson RA, Burton DR, Cohen FE, Prusiner SB: Strain-specified relative conformational stability of the scrapie prion protein. Prot Sci 200I, 10:854-863.

26. Bessen RA, Marsh RF: Distinct PrP properties suggest the molecular basis of strain variation in transmissible mink encephalopathy. J Virol 1994, 68:7859-7868.
Publish with Bio Med Central and every scientist can read your work free of charge

"BioMed Central will be the most significant development for disseminating the results of biomedical research in our lifetime. "

Sir Paul Nurse, Cancer Research UK

Your research papers will be:

- available free of charge to the entire biomedical community

- peer reviewed and published immediately upon acceptance

- cited in PubMed and archived on PubMed Central

- yours - you keep the copyright
BioMedcentral 